\title{
Governance, Civil Conflict, And Refugee Protection In Sub-Saharan Africa: A Primer
}

Bruce A. Forster, University of Nebraska at Kearney (Emeritus) and Arizona State University (Emeritus), USA Jessica D. Forster, Somali Bantu Association of Tucson, Arizona, USA

\begin{abstract}
This paper provides an introduction to the concepts of governance and state weakness, fragility or failure. Selected indices of performance are presented with an emphasis on Sub-Saharan Africa. As noted by the 2005 UK Commission for Africa "The most extreme breakdown of governance is war." The paper discusses the concepts and definitions of civil conflict and civil war, and the prevalence of civil war in Sub-Saharan Africa. Among the costs of civil war are the people who are displaced due to their fear for life amidst the conflict. If displaced persons exit the country they become refugees. The paper provides an introduction to the evolution of international humanitarian law since World War II to protect non-combatants, including refugees.
\end{abstract}

Keywords: Governance, Failing states, Civil Conflict, Refugees, International Humanitarian Law

\section{INTRODUCTION}

$\mathrm{n}$ a strong showing of support for strengthening economic and human development in Developing Countries, 189 countries signed the United Nations Millennium Declaration at the UN's Millennium Summit in September 2000 (UNGA, 2000). Central to the Declaration is the specification of a set of Millennium Development Goals (MDGs) The MDGs echo earlier goals embodied in the results of other meetings such as the 1991 World Health Conference, the 1994 Conference on Population and Development (the Cairo Consensus), the 1996 World Food Summit, and the 2000 World Education Forum. The spirit of the MDGs was endorsed by the 2001 Doha Development Agenda of the World Trade Organization (WTO, 2001), and the Monterrey Consensus (UN, 2002) and reaffirmed by the 2005 UN World Summit (UNGA, 2005). Support for the Declaration has been affirmed at the 2005 G8 Gleneagles Summit and, as this paper was being written, most recently affirmed by the 2009 G20 London Summit.

The set of MDGs provides a useful vehicle for discussing development issues facing individual Developing Countries as well as regions of the world. The set of MDGs is comprised the following eight Goals:

GOAL 1: $\quad$ Eradicate extreme poverty and hunger

GOAL 2: $\quad$ Achieve universal primary education

GOAL 3: $\quad$ Promote gender equality and empower women

GOAL 4: $\quad$ Reduce child mortality

GOAL 5: $\quad$ Improve maternal health

GOAL 6: $\quad$ Combat HIV/AIDS, malaria, and other diseases

GOAL 7: $\quad$ Ensure environmental sustainability

GOAL 8: $\quad$ Develop a global partnership for development

Each Goal has at least one target, and each target has at least one indicator/measure. These, generally speaking, specify performance outcomes to achieve by 2015 relative to the performance level in 1990 . The year 2008 marks roughly the half-way mark between the starting date of 2000 and the target date of 2015 . The World 
Bank (2008) in its assessment of the progress towards meeting the MDGs observes that "[w]hile the MDG1 poverty reduction target will be met at the global level, Sub-Saharan Africa is likely to fall well short. ..... At the regional level, Sub-Saharan Africa lags on all MDGs...." Indeed, only South Asia competes for the lowest ranking on some MDGs; however, South Asia is expected to meet MDG1.

This paper considers some underlying reasons for the poor economic and human development performance in Sub-Saharan Africa (SSA). The subset of African countries which comprise the SSA region generally includes all African countries other than the coastal countries of North Africa. These countries are Algeria, Egypt, Libya, Morocco, Tunisia, and Western Sahara (Population Reference Bureau 2009). However, the Human Development Reports referenced in this paper, take the countries of Djibouti, Somalia and Sudan out of their SSA category and include them with the set of Arab Countries. Some reports omit some countries (e.g. South Africa) since they are anomalies to the research questions being addressed while other countries may be deleted due to data deficiencies. It is important to check which countries are included in the SSA group in the various reports. This paper places Djibouti, Somalia, and Sudan in the SSA tables whenever possible.

\section{GOVERNANCE}

"Governance is fundamental to development and economic growth." --- Atlas of Global Development 2009, World Bank.

"Governments may fail either because they do too little, or because they do too much." ---Sir Arthur Lewis, The Theory of Economic Growth, 1955, (cited in the Spence Report, 2008).

The general consensus of researchers and international organizations is that the major reason for poor economic and human development performance in developing countries is poor governance within those poor performing countries. The Atlas of Global Development (2009) provides a succinct definition of governance:

Governance describes the way public officials and institutions acquire and exercise authority to provide public goods and services, including education, health care, infrastructure, and a sound investment climate.

It adds that "good governance is associated with increased citizen participation and improved accountability of public officials."

It is probably obvious that the distinction between good governance and bad governance is not a simple binary one. Instead like the notions of fuzzy mathematics it is one of varying degrees. In order to discuss governance then a quantitative measure is needed. Absent quantitative indicators, the discussions of governance are rather like discussions of beauty - very subjective and frequently relying upon unstated preferences of the discussants.

One such indicator, the Country Policy and Institutional Assessment (CPIA) index, was developed in the 1970s by the World Bank to assist decision making in the allocation of funding from the International Development Association (IDA). The CPIA is comprised of 16 criteria grouped into the following 4 categories, or clusters:

1. Economic Management

2. Structural Policies

3. Policies for Social Inclusion/Exclusion

4. Public Sector Management and Institutions

Another index is the Mo Ibrahim Foundation's Ibrahim Index of African Governance which, as the name suggests, deals only with African countries (actually just those in Sub-Saharan Africa). The Ibrahim Index, developed in the early to mid-2000s, uses 57 criteria grouped into the following 5 categories: 


$\begin{array}{ll}\text { 1. } & \text { Safety and Security } \\ \text { 2. } & \text { Rule of Law, Transparency and Corruption } \\ \text { 3. } & \text { Participation and Human Rights } \\ \text { 4. } & \text { Sustainable Economic Opportunity } \\ \text { 5. } & \text { Human Development }\end{array}$

Not all researchers believe that weak governance is the major factor in producing poor performance. In its assessment of progress towards meeting the MDGs, the Sachs Report (UNMP, 2005) devotes a separate chapter to "Africa's special needs." The Sachs Report's explanation for the poor performance of Africa is that Africa is stuck in a poverty trap. The following structural reasons for vulnerability to the poverty trap are offered by the Report:

1. Very high transport costs and small markets

2. Low- productivity agriculture

3. Very high disease burden

4. A history of adverse geopolitics

5. Very slow diffusion of technology from abroad.

While stating that "The standard diagnosis of Africa is that the continent is suffering from a governance crisis", the Sachs Report is adamant that the problem is deeper- "Governance is an issue, but Africa's development challenges are much deeper." The Sachs Report (2005) argued that "there is no evidence that Africa's governance, on average is worse than elsewhere once we control for Africa's low income." The root problem according to the Sachs Report is the African poverty trap.

The World Bank (2005) directly challenged the Sachs conclusion that the cause of the Sub-Saharan Africa situation is a poverty trap asserting instead that there is "no systematic evidence supporting the empirical relevance of poverty traps." The World Bank (2005) supports the view that "improving governance is the biggest challenge facing developing countries," and furthermore, that "the perception that economic governance is weaker in SubSaharan Africa than in other regions is broadly supported by available indicators." Counter to the Sachs Report conclusion, the World Bank (2005) states that "empirical evidence suggests that the stronger causality effect is from governance to income and, once that is accounted for, most African countries have governance scores lower than would be expected on the basis of their income levels."

The Blair Commission Report (UK, 2005) views improvement in governance in Africa to be the main need-"Without progress in governance, all other reforms will have limited impact." This view is shared by other assessments such as the Monterrey Consensus, "good governance is essential for sustainable development." The UNDP (2003) states that "Governance - the policies and institutions that regulate interactions among individuals and groups in society-- is seen as part of the foundation for sustained growth and human development."

Deviations from what is viewed as good governance in countries leads to discussions of "weak", "fragile" or "failing" states. Some researchers use these labels as being interchangeable (OECD, 2008) while others use one or the other often without specifying the rules for inclusion/exclusion.

Rotberg (2002) lists a set of characteristics generally shared by failed states, and uses these to examine countries to determine which were failed states.

The World Bank (2007) offers the following definition of fragile states:

Fragile states are "countries that are facing particularly severe development challenges such as weak governance, limited administrative capacity, violence, or the legacy of conflict."

This definition is qualitative but does not provide sufficient direction as to which countries are to be included and which are to be excluded by the analyst. For example, how weak does a country's governance have to be for inclusion as a fragile state? The World Bank operationalizes the notion of fragile states by using its country CPIA scores. The issue then is in selecting a cutoff value for the CPIA below which countries are deemed to be 
fragile states. For the cutoff points, the World Bank adopted its criteria for classifying countries as Low Income Countries Under Stress (LICUS) for the allocation of funding. Fragile states are those with CPIA scores below 3.0, and those with CPIA scores between 3.0 and 3.2 are deemed marginally fragile. Using these values, in 2005 , there were 30 fragile states of which 16 are in SSA, and nine marginally fragile states of which seven are in SSA (World Bank 2007). The World Bank (2007) reports these states alphabetically rather than in numerical rank order.

Foreign Policy and the Fund for Peace use 12 criteria to produce The Failed States Index 2008 which ranks 177 countries relative to weakness or vulnerability. In the bottom 30 states are 16 SSA countries.

Rice and Patrick (2008) introduce another definition of weak states and a new index for assessment. They define Weak States as:

Countries that lack the essential capacity and/or will to fulfill four sets of critical government responsibilities: fostering an environment conducive to sustainable and equitable economic growth; establishing and maintaining legitimate, transparent, and accountable political institutions; securing their populations from violent conflict and controlling their territory; and meeting the basic human needs of their population.

The Rice and Patrick Index of State Weakness in the Developing World ranks 141 developing countries relative to their performance in the four critical areas in the above definition.

Results for the four indices discussed in this section are summarized in Table 1, along with Rotberg's (2002) subjective assessment.

Table 1: Indices of SSA Fragile States and Rotberg's Qualitative Assessment

\begin{tabular}{|c|l|l|l|l|l|}
\hline Rank & $\begin{array}{c}\text { FP/FfP Failed } \\
\text { States } \\
\text { Index 2008 } \\
\text { (bottom 16) }\end{array}$ & $\begin{array}{c}\text { Rice's and Patrick's } \\
\text { Index of State } \\
\text { Weakness 2008 } \\
\text { (bottom 16) }\end{array}$ & $\begin{array}{c}\text { World Bank's } \\
\text { CPIA 3.0 and Below } \\
\mathbf{2 0 0 7} \text { (bottom 16) }\end{array}$ & $\begin{array}{c}\text { Ibrahim Index } \\
\text { African Gov. 2008 } \\
\text { (Bottom 10) }\end{array}$ & $\begin{array}{c}\text { Rotberg's } \\
\text { (2002) } \\
\text { Subjective } \\
\text { Assessment }\end{array}$ \\
\hline 1 & Somalia & Somalia & Angola & Somalia & Somalia \\
\hline 2 & Sudan & D.R. Congo & Burundi & D.R. Congo & Angola \\
\hline 3 & Zimbabwe & Burundi & Central Afr. Rep. & Chad & Burundi \\
\hline 4 & Chad & Sudan & Chad & Sudan & D.R. Congo \\
\hline 5 & D.R. Congo & Central Afr. Rep. & Comoros & Angola & Liberia \\
\hline 6 & Cote d'Ivoire & Zimbabwe & D.R. Congo & Cote d'Ivoire & Sudan \\
\hline 7 & Central Afr. Rep. & Liberia & Rep. of Congo & Eritrea & Guinea \\
\hline 8 & Guinea & Cote d'Ivoire & Cote d'Ivoire & Nigeria & \\
\hline 9 & Ethiopia & Angola & Eritrea & & \\
\hline 10 & Uganda & Sierra Leone & Guinea & & \\
\hline 11 & Nigeria & Eritrea & Guinea- Bissau & & \\
\hline 12 & Niger & Chad & Liberia & & \\
\hline 13 & Burundi & Guinea-Bissau & Somalia & & \\
\hline 14 & Rep. of Congo & Ethiopia & Sudan & & \\
\hline 15 & Kenya & Rep. of Congo & Togo & & \\
\hline 16 & Malawi & Niger & Zimbabwe & & \\
\hline & & & & & \\
\hline
\end{tabular}

Consider first the rankings of the results of the Indices. Note that the ranking for the World Bank's CPIA is alphabetical not according to individual country scores. This means that the CPIA is not comparable to the other indices. For the three other indices there is considerable overlap. Consider the bottom 10 for the FP/FfP. Six of the Rice and Patrick bottom 10 are also in FP/FfP's ranking and seven of the Ibrahim bottom 10 appear in the FP/FfP bottom 10. Somalia comes in bottom ranked. FP/FfP and Rice and Patrick refer to Somalia as a failed state.

All of Rotberg's seven countries are in the Rice and Stewart bottom 10. Six of these are failed states, while Rotberg termed Somalia "the model of a collapsed state." 


\section{CIVIL CONFLICT}

“The most extreme breakdown of governance is war." ---UK Commission for Africa, 2005.

"Wars in Africa are on average relatively short and they tend to be among the bloodiest." --- Elbadawi and Sambanis (2000).

Researchers note that conflict is both a cause of countries becoming fragile, and an outcome of low economic performance in fragile states (World Bank 2007). Nafziger and Auvinen (2002) found "that the incidence of conflict in Africa exceeded the incidence in other developing regions of the world in the 1990s", and the number of deaths in Africa was by far the largest during the 1960-1995 period.

Before proceeding further with the discussion, we define some of the terms used above and others that occur in the literature.

A Conflict refers "an interaction between interdependent people who perceive incompatible goals and who expect interference from the other party if they attempt to achieve their goal (Draman ,2003). A civil conflict is a conflict between intra-state (as opposed to inter-state) parties. An armed conflict is a conflict featuring open combat with at least 25 battle related deaths per year (Draman, 2003).

A civil war is a civil conflict featuring open combat with more than 1000 battle related deaths per year. Some researchers use the 1000 battle related deaths as the threshold for civil war but without the annual requirement (Collier, 2000; Elbadawi and Sambanis, 2000). The 1000 battle deaths (annual or cumulative) is a proxy for the severity of the conflict. Sambanis (2004) provides a detailed discussion of "coding rules" and their implications for separating a civil war from a civil armed conflict. Sambanis notes that the battle death rule ignores civilian deaths due to the conflict. He argues that "civilians are targeted in civil war and are disproportionately affected by humanitarian disasters created by combatants to hold civilian populations hostage and gain control of territory." He also argues that refugees and internally displaced individuals could provide a measure of the human cost of the conflict. Sambanis provides a classification for civil conflict versus civil war which has nine components. While very reasonable in terms of content, the definition does not seem to have achieved broad usage. This is probably because it is much more complex than the battle death rule.

Civil war has become the dominant form of war. Between 1945 and 1977, about $80 \%$ of the victims of armed conflicts were a result of non-international conflicts (ICRC, 2006). Collier (2000) noted that 25 of 27 major armed conflicts in 1999 were civil conflicts. We will consider some research into the causes of civil war. Collier (2000) draws upon earlier work with a colleague, Anke Hoeffler, that uses a data set covering 161 countries for the period 1965-1999. During this time period there were 73 civil wars. Some of the war countries lacked sufficient data for a complete analysis and needed to be dropped leaving 47 civil wars in the set.

Countries with a high proportion of exports in their GDP were at elevated risk of civil war, with about 25\% being the crucial threshold. Countries which have experienced a prior civil war were at more risk of another war, and could face a conflict trap in which countries enter a cycle of civil war, a breathing period followed by another civil war. Such countries with large émigré populations residing in the US have a further elevated risk. Countries with little education are more likely to experience civil war. Countries in economic decline, or with rapid population growth, have elevated risk.

Overall, the risk of civil war was reduced following the end of the Cold War. Interestingly, and contrary to popular perceptions, increases in ethnic or religious diversity reduce the risk of civil war within countries. The exception to this result occurs for countries where there is a dominant ethnic group. Collier defines ethnic dominance as a situation for which one ethnic group represents $45 \%--90 \%$ of the total population. While Africa is more diverse than other developing countries, only $40 \%$ of African countries exhibit ethnic dominance compared to $57 \%$ in non-African developing countries which, other things being equal, should reduce the incidence of African civil wars relative to non-African countries. 
Income and wealth inequality had no impact on the risk of civil war, nor did a lack of democratic rights. These observations along with the inverse relationship between ethnic and religious diversity (except for countries with a dominant ethnic group) led Collier to conclude that objective "grievance" was not a cause of civil war.

Noting the positive relationship between the risk of civil war and the ratio of primary product exports to GDP, leads Collier to conclude that "greed" rather than grievance is a cause of civil wars. The nature of primary commodities leads them to become targets of predatory behavior defined as the "the use of force to extort goods or money from their legitimate owners." Predation not only may line the pockets of the predators, it may also assist in funding their side of the conflict.

Nafziger and Auvinen (2002) use Gini data (not available to Collier) to measure income inequality, and counter to the findings of Collier, found a relationship between civil war and inequality. They conclude, again counter to Collier, that "objective grievances of poverty and inequality contribute to war and humanitarian emergencies." They also found that education and employment differences, resource allocations and language discrimination contribute to conflicts. Their work supports Collier's findings 1) that natural resource products are an important source of conflict and 2) that ethnicity is not a source of conflict. In earlier work they found a positive relationship between the ratio of military expenditures to national income.

Collier and Hoeffler (2000) use their global model of civil war over the 1965-1999 time- period to assess the causes of civil war in Africa (defined as SSA minus South Africa). First, they verified that the global model provided a good fit for Africa. They find that Africa has seen an increase in the incidence of civil war while nonAfrican developing countries have seen a reduced incidence of civil wars over time. These divergent paths are explained by the differential economic performance of the two groups over the time period.

The Elbadawi and Sambanis results confirm the importance of income levels, and the rate of growth of income, and the exports of primary products in causing civil war in Africa. Contrary to Collier's and Hoeffler's results, Elbadawi and Sambanis found another cause of civil war to be the lack of strong democratic institutions.

\section{REFUGEE PROTECTION}

"In civil wars, women and children always fare worst." ---The Economist, February 21, 2009, page 61.

It is generally understood that the damages associated with civil war are not confined to the battlefield. Collier (2004) observes that more than half of the damages spill over onto neighboring countries. The costs of civil wars "are borne by non-combatants within the country, by future inhabitants, and by neighbours."

Non-combatants may flee their homes in search of safety from the bloody battles and marauding forces amongst the civilian population. They will either settle in camps within their home country, or flee across the border to camps in nearby countries. These persons are displaced from their homes. For current purposes, we classify these conflict-induced, displaced persons (DPs) into two simplified groups. Those remaining within their home country are internally displaced persons (IDPs), while those displaced persons leaving their home country are refugees. The global number of displaced persons by category is given in Table 2 (The demographic profiles discussed below are from the UNHCR (2009)).

Table 2: Number of Displaced Persons by Category at end-2008 ${ }^{2}$

\begin{tabular}{|c|l|c|}
\hline Row Number & \multicolumn{1}{|c|}{ Category of DPs } & \multicolumn{1}{|c|}{ Number of DPs (in millions) } \\
\hline 1 & Refugees & 15.2 \\
\hline 2 & Asylum-seekers & 0.8 \\
\hline 3 & Conflict-Induced IDPs & 26 \\
\hline 4 & $\begin{array}{l}\text { Total Refugees + Asylum seekers+Conflict-induced IDPs } \\
\text { Rows (1+2 +3) }\end{array}$ & 42.0 \\
\hline 5 & Natural Disaster generated IDPs & 25.0 \\
\hline 6 & $\begin{array}{l}\text { Total IDPs } \\
\text { Rows (3+5) }\end{array}$ & 51.0 \\
\hline 7 & $\begin{array}{l}\text { Total DPs ( Refugees +Asylum-seekers + IDPs) } \\
\text { Rows (4 +5) }\end{array}$ & 67.0 \\
\hline
\end{tabular}


Before proceeding further with the demographic profile of DPs, we need to lay some institutional foundations. Following World War II, the concern for war-generated DPs resulted in the UN's General Assembly establishing, in 1950, an Office of the United Nations High Commissioner for Refugees (UNHCR).

The 1951 United Nations Convention relating to the Status of Refugees as modified by its 1967 Protocol (hereinafter, the 1951 Convention and 1967 Protocol) defines a refugee as a person who:

owing to well-founded fear of being persecuted for reasons of race, religion, nationality, membership of a particular social group or political opinion, is outside the country of his nationality and is unable or, owing to such fear, is unwilling to avail himself of the protection of that country; or who, not having a nationality and being outside the country of his former habitual residence is unable or, owing to such fear, is unwilling to return to it.

The 1967 Protocol removed the date requirement (achieve refugee status for the time period ending in 1951 ) and the associated geographic limitations (Europe) specified in the "original" 1951 version.

Persons in refugee-like situations are those persons with refugee- like characteristics but for whom such status has not been determined. Since 2007, these persons are included in the total refugee category.

Table 3 provides the 2008 refugee count for UNHCR regions. Table 4 presents the main refugee countries of origin while Table 5 shows the number of refugees in the 10 largest host countries.

Table 3: Refugee count for UNHCR regions, $2^{2008}{ }^{2}$

\begin{tabular}{|l|c|c|c|}
\hline \multicolumn{1}{|c|}{ UNHCR Region } & Refugees & Persons in Refugee-like situations & $\begin{array}{c}\text { Total Refugees } \\
\text { End of 2007 }\end{array}$ \\
\hline Central Africa and Great Lakes & 978,200 & 27,800 & $1,006,000$ \\
\hline East and Horn of Africa & 763,900 & & 763,900 \\
\hline Southern Africa & 161,100 & & 161,100 \\
\hline West Africa & 175,300 & & 175,300 \\
\hline $\begin{array}{l}\text { Total Africa } \\
\text { (excluding North Africa) }\end{array}$ & $\mathbf{2 , 0 7 8 , 5 0 0}$ & $\mathbf{2 7 , 8 0 0}$ & $\mathbf{2 , 1 0 6 , 3 0 0}$ \\
\hline Americas & 500,000 & 303,500 & 803,500 \\
\hline Asia and Pacific & $2,577,800$ & $1,018,300$ & $3,596,100$ \\
\hline Europe & $1,616,000$ & 5,700 & $1,621,700$ \\
\hline Middle East and North Africa & $2,278,200$ & 72,800 & $2,351,000$ \\
\hline Overall Total & $\mathbf{9 , 0 5 0 , 5 0 0}$ & $\mathbf{1 , 4 2 8 , 1 0 0}$ & $\mathbf{1 0 , 4 7 8 , 6 0 0}$ \\
\hline
\end{tabular}

Table 4: Seven Largest Countries of Origin for UNHCR Refugees, 2008

\begin{tabular}{|l|c|}
\hline \multicolumn{1}{|c|}{ Country of Origin For Refugees } & Number of Refugees (including Refugee-like) \\
\hline Afghanistan & 2.8 million \\
\hline Iraq & 1.9 million \\
\hline Colombia & 374,000 \\
\hline Sudan & 419,000 \\
\hline Somalia & 561,000 \\
\hline Burundi & ---- \\
\hline D.R. Congo & 368,000 \\
\hline
\end{tabular}

Afghanistan was the largest originator of refugees, followed by Iraq. Ninety-six percent of Afghan refugees settle in just two countries-Pakistan and Iran, both of which border Afghanistan. Refugees from Iraq locate predominantly in Syria. Together, Afghanistan and Iraq accounted for almost half of the 2008 refugees. Pakistan, Syria and Iran are the three largest host countries with over one million refugees each. These cases demonstrate a general result. Over three quarters of refugees locate in neighboring countries, or in other countries within their region (UNHCR, 2009). 
Table 5 presents major host countries for refugees of concern to the UNHCR.

Table 5: Ten Largest Host Countries for UNHCR Refugees, 2008

\begin{tabular}{|l|c|}
\hline \multicolumn{1}{|c|}{ Host Country } & Number (In millions) \\
\hline Pakistan & 1.8 \\
\hline Syrian Arab Rep. & 1.1 \\
\hline Islamic Rep. of Iran & 1.0 \\
\hline Germany & 0.6 \\
\hline Jordan & 0.5 \\
\hline Chad & 0.3 \\
\hline Tanzania & 0.3 \\
\hline Kenya & 0.3 \\
\hline China & 0.3 \\
\hline United Kingdom & 0.3 \\
\hline
\end{tabular}

In addition to specifying the formal definition of refugees, the 1951 Convention and 1967 Protocol, along with their Articles, guide the efforts of the UNHCR in meeting the mandate of the Office, and they set forth the mandatory treatment of refugees. A brief summary of some of the major standards can be found in the UNHCR's one-page Mission Statement found on its web-site.

The 1951 Convention and 1967 Protocol did not deal with IDPs. As a result, the UNHCR had no formal mandate to work with IDPs. However, over time, given its experience with refugees the UNHCR was called upon to provide assistance to those working with IDPs. This was formalized in 2005, and the UNHCR now takes the lead role with assisting IDPs when appropriate. The UNHCR provides a document, Guiding Principles on Internal Displacement which provides a definition of IDPs in addition to 30 guiding principles for the treatment of IDPs. The discussion from here on deals only with refugees and the various documents designed to protect them.

The Fourth Convention of the 1949 Geneva Conventions deals with the protection of civilians in armed conflict situations. Article 4 of this Convention states that any person who is a national of a party-state in conflict shall be protected by the terms of this convention as well as those who under protection of a state other than that of their own nationality- which can absolutely be applied to the status of refugees (United Nations, 1949). However, there has been some controversy about whether or not refugees are or are not covered by the rights set forth in the Fourth Convention. In order to address this controversy and ensure that it is understood that refugees are considered protected by the Fourth Convention, the "additional protocol" (Protocol II, 1977) was written (Gillard, 2005)). Article 27 of the Fourth Convention stipulates that women should be given specific protection against sexual crimes such as "rape, enforced prostitution and any form of indecent assault." This Convention is one of the first, and most important, documents regarding the rights of persons during conflict and although the issue of gender-based protection is loosely discussed, this particular article is the beginning of gender and international law. In the decades that have passed since the end of World War II, international law has been developed to be much more gender sensitive.

Within the Fourth Convention, the issue of the care and protection of children is mentioned in a number of articles. It is easy to understand the special vulnerability of children, especially in times of conflict and duress. Article 24 of the Fourth Geneva Convention explains that children under the age of fifteen are taken care of, specifically, they are to be provided with necessary resources to survive such as food and shelter and shall not be left to fend and support for themselves. It also states that these children shall be moved to the protection of a neutral state in order to be removed from the dangers of conflict. While it is true that most children are moved into refugee camps in a neutral party's country, the children are not removed from the dangers of the conflict. They still face the dangers of stress inflicted upon community members which relates to the violence against children, the sexual violence invoked upon these children, or the recruitment of child soldiers from these camps.

Article 50 of this Convention also specifies that there should be special emphasis on the education of children of armed conflict, especially in the case of children who have been separated from their families or the 
families have been killed leaving the child with little or no protection. In these cases, it is advised that the children are to be educated and cared for by responsible persons, preferably by persons of their own personal beliefs or traditions. While it is understandable that it may not be possible to refer children to functioning education programmes while living in refugee camps, the fact that many children have been sent to schools outside of the refugee camps which has then become a main place for the abuse is in a clear violation of this article and the right of the child. In the case of recruitment of child soldiers from the refugee camps, it is clearly stated in Article 50 that the children of armed conflicts shall not be enlisted into any organisations.

The primary document focused on the issue of women's rights in international law is the 1979 Convention on the Elimination of All Forms of Discrimination against Women (CEDAW). This document is of particular importance as it is the first document to seriously address the vulnerability of women and the essential need to focus on special rights to protect women. In the introduction of this Convention, it is reiterated that women and men are born as equal persons. However it is due to widespread discrimination against women despite this declaration of universal equality, women are in need of additional emphasis on their rights as women in addition to their rights as human beings. The first several articles are meant to show that women are entitled to their basic human rights as well as specific rights which are sensitive to the lives of women.

The 1993 Declaration on Eliminating Violence against Women goes beyond the CEDAW by drawing further attention to the issue of violence in addition to discrimination of women. In the foreword of the document, the General Assembly notes the historical inequality between men and women and there has been:

- $\quad$ [concern] that some groups of women, such as women belonging to minority

- $\quad$ groups, indigenous women, refugee women, migrant women, women living in

- $\quad$ rural or remote communities, destitute women, women in institutions or in

- $\quad$ detention, female children, women with disabilities, elderly women and

- $\quad$ women in situations of armed conflict, are especially vulnerable to violence.

Nearly all of the Articles of the 1993 Declaration have been broken by the violence against women within the refugee camps. Article 2 explains that violence against women shall include any sexual, physical or psychological violence invoked against women by any persons within the family or household including from elder family members towards the young females of the family. Violence against women also includes any sexual, physical or psychological violence by anyone in the community and lastly, none of these types of violence should be condoned by the state. The fact that many local officials within the state of the refugee camps have not diligently pursued the cases of domestic violence and sexual violence is in violation of this article.

Article 3 details that women shall be treated fairly and equally in "political, economic, social, cultural, civil" fields. Especially important to note is Article 4 in which all states are called upon to ensure to their best abilities that violence against women is condemned despite religious or cultural customs and traditions which may either support or not denounce violence against women. Article 4 also emphasizes the importance for states to have action plans in order to fight issues of violence against women and working towards a society more conducive to meeting women's needs. Article 5 emphasises the importance of cooperation between the United Nations, nongovernmental organizations, and the governments in order to ensure that the best possible implementation of this declaration is in place. Each one of these articles has been violated by officials who have ignored reports submitted by abused women, by aid workers who have committed the violations themselves, as well as those officials who have not worked towards resolving investigated possible cases of abuse. There has not been appropriate emphasis on educating persons living within the camp, where there is a high threat of abuse due to stress and trauma, about the rights of women under international law.

In 1989, the United Nations General Assembly adopted the Convention on the Rights of the Child, a more specific document relating to the special needs of children throughout the world. While there are additional documents written throughout the last century regarding the special needs of children, the Convention of the Rights of the Child addresses more modern issues of child's needs and special protection. 
Article 9 explains that no child shall be removed from his parents or family against his or her will. However, in the event that there is abuse or neglect by the child's parents or guardians, the State is expected to help in the protection of the child and work towards movement in the best interests on the child. By this article, as well as those addressed in basic human rights documents, children have the right to live a life without abuse and inflicted harm even when those causing the harm may be the natural or legal caregivers to the child. Therefore, the State is responsible to take any reports of abuse from children as a serious offence and act within their means to provide the children with a safe alternative to avoid further abuse.

Articles 20-22 are of particular importance to the issue of orphaned or separated refugee children. In these articles, it is explained that in the case of a child without parents or guardians that the State must work towards finding an appropriate means of supervision such as a foster family or adoption. While this often does indeed occur within refugee camps as children are placed into foster families of their same ethnic or religious background as is emphasised in this document, the children are often abused by these foster or adoptive families. States are responsible for the protection of the child even after the placement in a foster family or an adoptive family.

Given the additional stress surrounding issues of civil war, armed conflict, and refugee camps, it is understandable that there is little time and energy to be placed on following up on the placement of children but for the sake of the children and in the name of human rights and international law, there should be stronger emphasis on reinforcing the protection of vulnerable children. Especially important here, is Article 22, which notes that there should be special cooperation between State parties, the United Nations, and non-governmental organisations in order to ensure the protection of children in this particular situation. Though there are additional factors surrounding the refugee camps and armed conflict in relation to the child the State is encouraged to seek additional help if needed.

Article 27 states that children have the right to an adequate standard of living regarding their emotional, physical, mental, social lives, etc. Article 34 states that State parties are required to do everything within their capacity to protect children from any kind of sexual exploitation or abuse and Article 36 says that the States must do everything they can in order to protect the children from all other forms of exploitation prejudicial to any aspects of the child's welfare. Article 38 says that States must do all they can to protect the children from being involved in hostilities, such as acting in conflict, and are responsible to ensure that the rights under international humanitarian law are respected and upheld during the time of armed conflict.

Each one of these articles addresses an issue that has been shown to be a serious issue inside of refugee camps. According to this Convention, children are allotted the right to be young, to be youthful, to be children, at the very least. These children deserve to be protected from violence and sexual exploitation. It is understandable that protection cannot always be guaranteed because complete protection is rarely possible during times with duress or conflict. However, the extent to which the violence and exploitation of children occurs within the refugee camps is a clear violation of the rights of children by International Law. The United Nations and the High Commissioner for Refugees have absolutely realised the vulnerability of women and children throughout the world and have taken steps towards providing them with additional protection. Despite these efforts, there still exists a serious problem in their protection and their rights as children continue to be violated.

The previous works discussed in this section have concerned conventions, protocols and declarations which lay out the rights of refugees to be protected. What happens when these are violated?

The judicial body for these infractions is the International Criminal Court which is very much in its infancy and as such it has developed only baby teeth so far. The Rome Statute of the International Criminal Court, 2002, established the International Criminal Court (ICC) as a permanent institution hosted at The Hague in the Netherlands.

\section{CONCLUSION}

The general consensus of international NGO's is that good governance is the foundation for a countries economic growth performance. Less than "good" governance potentially leads to fragile, or failing, states. Indices 
of state failure considered in this paper show broad agreement as to which countries are failing to some degree. All agree that Somalia is in the worst shape. Countries which are failing are prone to civil wars and poor economic, and human, development.

Since WWII a substantial body of international humanitarian law has developed which provide protection to civilians, especially women and children and refugees, during times of civil war. Only recently has an international court been instituted to provide the judicial framework for alleged violators. What is lacking is an appropriate system for ensuring that alleged violators appear before an appropriate judicial body.

\section{SUGGESTIONS FOR FUTURE RESEARCH}

1. Why has governance been so poor in so many SSA countries since independence?

2. Why are nations reluctant to enforce international humanitarian law? How do the concepts of sovereignty and the Responsibility to Protect affect the enforcement of these laws?

\section{AUTHOR INFORMATION}

Dr. Bruce A. Forster holds a BA in Mathematics and Economics from the University of Guelph in Canada, and a $\mathrm{Ph} \mathrm{D}$ in Economics from the Australian National University. He is co-author of Economics in Canadian Society (John Wiley) and author of The Acid Rain Debate (Iowa State University) and over 40 journal articles, book chapters and special proceedings. From 1989 to 1991 Dr Forster was an Associate Editor of the Journal of Environmental Economics and Management. From 1991 to 2009 Dr. Forster served as a Business dean at the University of Wyoming, Arizona State University's West campus, and the University of Nebraska at Kearney. Dr. Forster retired from UNK at the end of May 2009, and holds Professor emeritus titles from UNK and ASU.

Jessica D. Forster holds a BA in Political Science and Latin American Studies, with a Minor in Spanish, and an LLM in International Law with International Relations from the University of Kent's Brussels School of International Studies. While doing her Masters studies she spent three weeks as a volunteer in Kenya. Since completing her dissertation on violence to women and child refugees in Africa she has been employed by the Somali Bantu Association of Tucson, Arizona an association devoted to assisting recent refugees from Africa.

\section{FOOTNOTES}

1. An earlier version of this paper was presented at the 2009 Annual Conference of the Canadian Economic Association, Toronto, May, 2009 and the $9^{\text {th }}$ Annual Hawaiian International Business Conference, Honolulu, June, 2009.

2. Table 3 includes only those refugees under the jurisdiction of the UNHCR while Table 2 provides all known refugees including 4.7 million Palestine refugees under the jurisdiction of the United Nations Relief and Works Agency for Palestine Refugees in the Near East.

\section{REFERENCES}

1. Collier, Paul, "Economic Consequences of Civil Conflict and Their Implications for Policy." World Bank Manuscript, 2000.

2. Collier, Paul, "Development and Conflict", Oxford University Manuscript, 2004.

3. Collier, Paul. and Anka A. Hoeffler. "On the Incidence of Civil War in Africa", World Bank Manuscript, 2000.

4. Commission for Africa, Our Common Interest, London. (also known as the Blair Commission Report), 2005.

5. Commission on Growth and Development, The Growth Report: Strategies for Sustained Growth and Inclusive Development, (also known as the Spence Report), 2008.

6. Diplomatic Conference of Geneva (DCG), "Convention (IV) relative to the Protection of Civilian Persons in Time of War." 1949. 
7. Draman, Rasheed, "Poverty and Conflict in Africa: Explaining a Complex Relationship," paper prepared for the Experts Group Meeting on Africa-Canada Parliamentary Strengthening Program, Addis Ababa, 2003.

8. The Economist, "Civilians in war zones: Women and children fare worst", February 21-27, p. 61, 2009.

9. Elbadawi, Ibrahim and Nicholas Sambanis, "Why Are There So Many Civil Wars in Africa? Understanding and Preventing Violent Conflict", Journal of African Studies, Vol. 9, pp. 244-269, 2000.

10. Foreign Policy and the Fund for Peace (FfP), "The Failed States Index," Foreign Policy, July/ August, 2008.

11. Mo Ibrahim Foundation, The Ibrahim Index of African Governance, 2008.

12. Gillard, Emanuela-Chiara, "Humanitarian Law, Human Rights, and Refugee Law-Three Pillars", International Committee of the Red Cross, 2005.

13. Nafziger, E. Wayne and Juha Auvinen, "Economic Development, Inequality, War, and State Violence", World Development, Vol. 39, No.2, pp.153-163, 2002.

14. OECD, "Concepts and Dilemmas of State Building in Fragile Situations: From Fragility to Resilience," 2008.

15. Population Reference Bureau, World Population Data Sheet 2009, 2009.

16. Rice, Susan and Stewart Patrick, "Index of State Weakness in the Developing World," Brookings Institution, 2008.

17. Rotberg, Robert I. "Failed States in a World of Terror", Foreign Affairs, Vol. 81, No. 4, pp. 127-140, 2002.

18. Sambanis, Nicholas, "What is Civil War?” Journal of Conflict Resolution, Vol.48, No. 6, pp. 814-858, 2004.

19. United Nations Development Program (UNDP), Human Development Report (HDR) 2003, Millennium Development Goals: A Compact Among Nations to End Poverty, 2003.

20. United Nations (UN), Report on the International Conference on Financing for Development ( also known as the Monterrey Consensus), 2002.

21. United Nations General Assembly (UNGA), Convention on the Elimination of all Forms of Discrimination against Women (CEDAW), 1979.

22. United Nations General Assembly (UNGA), Convention on the Rights of the Child, 1989.

23. United Nations General Assembly (UNGA), Declaration on Eliminating Violence Against Women: A/RES/48/104, 85th plenary meeting, 1993.

24. United Nations General Assembly (UNGA), United Nations Millennium Declaration, 2000.

25. United Nations General Assembly (UNGA), United Nations 2005 World Summit Outcome, 2005.

26. United Nations High Commissioner for Refugees (UNHCR). 2008 Global Trends: Refugees, Asylumseekers, Returnees, Internally Displaced and Stateless Persons, 2009.

27. United Nations Millennium Project (UNMP), Investing in Development: A Practical Plan to Achieve the Millennium Development Goal, (also known as the Sachs Report), 2005.

28. World Bank, Global Monitoring Report (GMR) 2005, "Millennium Development Goals: From Consensus to Momentum, 2005.

29. World Bank, Global Monitoring Report (GMR) 2007, Millennium Development Goals Confronting the Challenge of Gender Equality and Fragile States, 2007.

30. World Bank, Global Monitoring Report (GMR) 2008, MDGs and the Environment: Agenda for Inclusive and Sustainable Development" 2008.

31. World Bank, Atlas of Global Development, second edition, 2009.

32. World Trade Organization, (WTO). Ministerial Declaration (also referred to as the Doha Development Agenda), 2001. 